\title{
AC 2012-3790: IMPACT OF SELF-EFFICACY ON INTEREST AND CHOICE IN ENGINEERING STUDY AND CAREERS FOR UNDERGRADUATE WOMEN ENGINEERING STUDENTS
}

\section{Dr. Patricia R. Backer, San Jose State University}

Patricia Backer has been a faculty member at SJSU since 1990 and now serves as Director of General Engineering. In her current role, Backer is involved in developing and assessing outreach programs to increase the number of women and underrepresented students in engineering.

\section{Dr. Rona Tamiko Halualani, San Jose State University}

Rona T. Halualani is a Full Professor of diversity and intercultural communication in the Department of Communication Studies as San Jose State University. 


\title{
Impact of Self-Efficacy on Interest and Choice in Engineering Study and Careers for Undergraduate Women Engineering Students
}

\begin{abstract}
Self-efficacy refers to the belief in a persons' ability to perform a specific task. Starting in middle school, girls tend to underestimate their abilities in STEM. This confidence gap among girls persists through high school into college [1]. This gap is presumed to be partially responsible for the gender gap in engineering and other STEM fields (e.g. computer science, physics). In 2006, women only earned 19.5\% of the undergraduate BS engineering degrees in the U.S. Using the Life Course Expectancy Framework, this paper investigates the motivations of women students at San José State University to pursue engineering careers, including their level of self-efficacy and sources of academic support, and the cultural influences that shape their interest and choice in engineering disciplines and careers for women. Using an adapted version of the Engineering Student Annual Survey, developed by the NSF-funded Assessing Women and Men in Engineering, the researchers explored the personal and cultural motivations of female students at San José State University. With a highly diverse student population in the College of Engineering and across the university, the researchers have been able to delve into the relationship between cultural expectations and STEM aspirations. The authors examined data from student Longitudinal Assessment of Engineering Self-Efficacy (LAESE)surveys. Despite the shrinking number of women engineering students at San José State University , the selfefficacy levels of the women engineering students were high. The authors can surmise that women who choose to study engineering at SJSU feel confident in their abilities to succeed in engineering and or project such confidence given the male-dominated terrain of Engineering.
\end{abstract}

\section{A. Theoretical basis for the research}

There is little empirical research on the specific impact of cultural attitudes about gender roles on girls' interest and career choice in Science, Technology, Engineering, and Mathematics (STEM) fields, particularly about STEM interest and career choice for young women of color. Cultural attitudes about gender roles refer to "beliefs and expectations about what is appropriate for males and females in terms of behavior and, in this case, career choice goals” in specific racial and ethnic communities [2].

Research has shown that female students pursue a much narrower set of career opportunities than do boys and, in the labor force, only six percent of women are employed in "non-traditional careers". Also, female students are "more likely to be derailed by negative perceptions of their abilities, attributing setbacks to personal failure” [3]. Attitudes towards STEM fields also differ among students of color, where messages from different groups and communities can conflict with each other and result in a "subtractive education" [4]. Cultural influences such familial obligations and culturally specific gender roles play a significant role in shaping Latina girls' career choices [5] and can create added pressure to reconcile careers with cultural values [6][7]. Recently, researchers have focused their attention to the career self-efficacy of women of color. 
Latina engineering students have been found to have lower levels of engineering career selfefficacy and self-efficacy for requirements in their academic programs.

Starting in middle school, girls tend to underestimate their abilities in STEM [8]. This confidence gap among girls persists through high school into college [9]. This confidence gap is presumed to be partially responsible for the gender gap in engineering and other STEM fields (e.g. computer science, physics) [10].In 2009, women earned only $17.8 \%$ of bachelor's degrees in engineering in the U.S. [11]. Although recent research indicates that the confidence gap may be closing (see Rittmayer et al [12] for a review), the numbers of women choosing engineering careers has not appreciable changed.

Self-efficacy refers to the belief in a person's ability to perform a specific task [13]. It is defined as one's individual judgment about the ability to plan and implement a series of actions required to reach a specific goal [14]. Self-efficacy is a predictor of academic achievement [15]; and, in STEM fields, individuals with high levels of self-efficacy have higher performance levels [16][17][18][19] and longer persistence in STEM fields than those with lower levels of selfefficacy [20].

Research into the self-efficacy of women engineering students has shown mixed results. Many women who leave engineering have less confidence than those who stay in engineering although their performance is the same or better than students who stay [21][22][23][24]. Also, some studies have reported that women in STEM disciplines have lower levels of self-efficacy than men [25][26][27]. However, other research has shown there is no statistically significant difference in self-efficacy between men and women engineering students [28][29]. Below, we will highlight some of the recent research in this area.

A six-year study of STEM students at the University of Washington [30] found that most women who switched out of engineering (77.9\%) cited discouragement and a loss of self-efficacy as factors. Marr and Bogue [31] conducted a longitudinal study of women engineering student selfefficacy using data from five institutions across the U.S. The results of their study of 164 women engineering students showed there was a positive increase in self-efficacy among students in three self-efficacy measures (coping self-efficacy, second engineering self-efficacy, and math outcomes expectations) and reduced self-efficacy in feelings of inclusion in engineering. In contrast, Reisberg et al. conducted a study analyzing the effect of gender on a range of related supports to explain three dimensions of self-efficacy: work, career, and academic within undergraduate engineering [32]. Their survey respondents totaled in 990 sophomore students, 216 of which were female. Their findings sustain prevailing research results suggesting that women have lower academic self-efficacy than men at the beginning of their undergraduate engineering careers. This is congruence with a study done of 519 undergraduate engineering majors' self-efficacy belief at a Midwestern university. In this study, Barrow and Concannon [33] found that there was no significant disparity of mean engineering self-efficacy scores by gender, ethnicity or transfer status. However, it was found that women had a lower mean coping self-efficacy than men. This suggests a lower persistence rate in engineering majors.

For the past two decades, the percent of engineering degrees awarded to women in the U.S. has stagnated at a level of less than $20 \%$, in spite of the fact that high school girls have been taking 
more mathematics and science classes than ever before [34]. The National Center for Education Statistics at the U.S. Department of Education found that female high school graduates earned slightly more credits in mathematics and science than male high school graduates.[35] Yet, they are less likely to pursue an career in math, science, or engineering than their male peers. The College of Engineering at San José State University has also witnessed an overall decrease in the number of women engineering students, dropping from 19\% in 2001 to 14\% in 2011.

Table 1. Women Undergraduates in the College of Engineering at San José State University

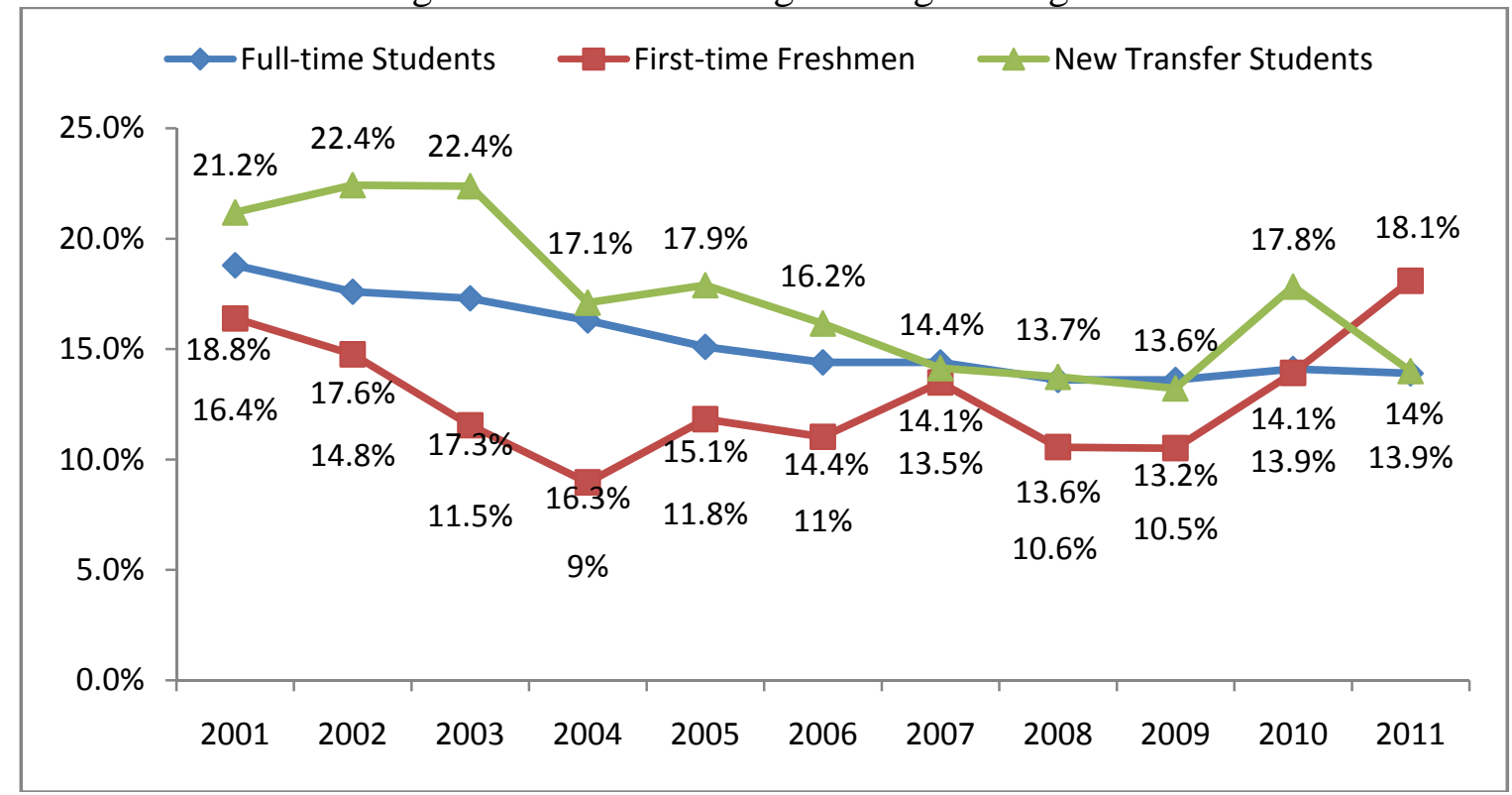

B. Research questions

As part of its continual improvement process, the College of Engineering at San José State University undertook an in-depth study to analyze the experiences and perceptions of women undergraduate engineering students at San José State University. For this study, there were two research questions.

Research Question 1. What motivates Women students to pursue Engineering careers? Research Question 2. What are the cultural influences that shape interest and choice in Engineering study and careers for Women students?

\section{Methodology}

The design of this study departs from the dominant "pipeline approach" typically used to study girls and boys and their choice (or non-choice) of STEM careers [36]. A common conclusion about women's career choices, using the pipeline model, is that "the under-representation of women in science is attributable to women's relatively higher rates of attrition from the science pipeline" [37]. The pipeline model is not sufficient to explain the behavior of women in STEM [38]; a comparative study of women in different academic fields demonstrated that the pipeline model did not explain the disparity in women among academic scientists despite the flow of PhD students being the same [39]. This study instead uses a Life Course Perspective (LCP) as our 
conceptual framework [12]. According to this perspective, "Individuals begin to develop ideas of normative family behavior and the proper trajectory of their lives at an early age...” [40]. This research will explore career choice as occurring under the multiple influences of family, community, culture, and educational institutions.

This research study had two major activities. In this paper, the authors describe the results of the first activity, a survey of all College of Engineering (CoE) women students at San José State University in Fall 2011. The second major activity, focus groups of women CoE students will be completed in Spring 2012.

In Fall 2011, the CoE had 440 women undergraduate students; these students were the population used for this survey. The authors selected the Longitudinal Assessment of Engineering Self-Efficacy (LAESE) [41] to measure self-efficacy, confidence, and outcomes expectations, all of which have been shown to influence student success in engineering [42]. The LAESE survey is a tested and validated survey designed to measure the self-efficacy of women in engineering. The LAESE has six subscales (see Table 2) and it has been validated with acceptable Cronbach's Alpha reliability coefficients which range from 0.73 to 0.87 . This survey was distributed online using SurveyMonkey.

\begin{tabular}{|l|}
\hline Table 2. LAESE subscales [42] \\
\hline Subscales \\
1. Engineering self-efficacy 1 (5 items, alpha $=.82)$ \\
2. Engineering career expectations $(7$ items, alpha $=.84)$ \\
3. Engineering self-efficacy II (6 items , alpha $=.82)$ \\
4. Feeling of inclusion (4 items, alpha $=.73)$ \\
5. Efficacy in coping with difficulties $(6$ items, alpha $=.78)$ \\
6. Math outcomes efficacy $(3$ items, alpha $=.84)$ \\
\hline
\end{tabular}

\section{Results}

The authors collected responses from 79 female students in the College of Engineering which stands as an $18 \%$ response rate. The student respondents were almost equally distributed among the four undergraduate class levels; however, because of the high number of units required for graduation in an engineering major, the largest subgroup was composed of fourth and fifth year students $(n=33)$. The ethnicity data for the respondents is displayed in Table 3 . The three largest ethnic subgroups responding to the survey were white women students ( $n=27)$, Asian women students $(n=34)$, and Latina students $(n=16)$. Data on each woman's department affiliation is included in Table 4. The authors received responses from a highly diverse group and representing a broad range of departments within the College. The extraordinary diversity of Santa Clara County and the City of San José provide the primary context for our student body. The 1.8 million residents of Santa Clara County are 44\% white, 26\% Asian, 24\% Latino/a, and $3 \%$ African American. The county has had a pluralist majority for many years, with more Asian and Latino/a immigrants than any other Bay Area county. The vast majority (83\%) of SJSU's incoming freshmen class comes from the greater San Francisco Bay Area; this brings us a diverse student body to San José State University and the College of Engineering each academic year. 
Table 3. Ethnicity of the female survey respondents.

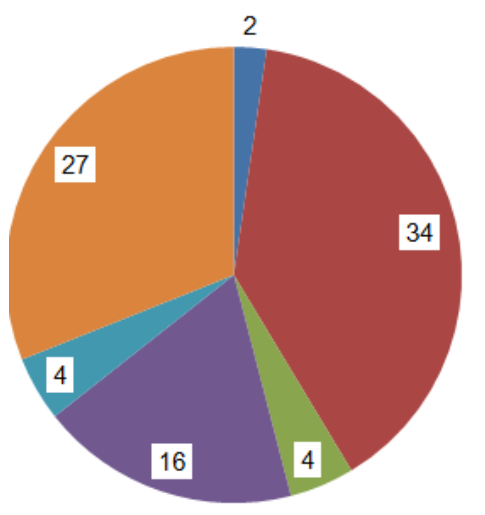

Table 4. Departmental affiliations of female survey respondents.

\begin{tabular}{|l|c|}
\hline Department & Number \\
\hline Aviation and Technology & 2 \\
\hline Chemical and Materials Engineering & 7 \\
\hline Civil and Environmental Engineering & 15 \\
\hline Computer Engineering & 16 \\
\hline Electrical Engineering & 12 \\
\hline General Engineering & 6 \\
\hline Industrial and Systems Engineering & 5 \\
\hline Mechanical and Aerospace Engineering & 12 \\
\hline Software Engineering & 1 \\
\hline Did not respond & 3 \\
\hline \multicolumn{2}{|r|}{ Total } \\
\hline
\end{tabular}

Most of the survey respondents were satisfied with their choice of engineering major (50 out of 79 students). However, few of the students indicated that they were planning to change their majors; four students were already planning to changes majors, two were likely to change majors, and seven said there was a 50\% chance they would change their majors. The survey respondents were very active in student organizations at San José State University (see Table 5). More than $50 \%$ of the women survey respondents were active in disciplinary student organizations while 21 out of 60 students were involved in the Society of Women Engineers (SWE). Fewer female students took advantage of San José State University 's student support activities such as the Learning Assistance Resource Center (20\%) and the XXX Writing Center (13.3\%).

\section{Table 5. Student participation in academic activities.}

Answer Options

Response Count Response Percent

An engineering society (such as American Society of Mechanical Engineers)

$56.7 \%$

Activities sponsored by your department or major

$45.0 \%$

SWE (Society of Women Engineers)

$35.0 \%$

LARC (Learning Assistance Resource Center)

$20.0 \%$

Facilitated Study Groups

$16.7 \%$

MEP (MESA Engineering Program)

Writing Center

A social sorority or fraternity

$13.3 \%$

$13.3 \%$

$11.7 \%$

An intramural or university sports team

$11.7 \%$

SOLES (Society of Latino Engineers and Scientists)

$11.7 \%$

BASE (Black Alliance of Scientists and Engineers)

$10.0 \%$

EOP (Educational Opportunity Program)

$10.0 \%$

CELL (Community for Engineering Learning and Living)

$6.7 \%$

ELCAS (Engineering Learning Community for Academic Success)

PMP (Peer Mentoring Program) 
The authors did not require students to answer every question and, as a result, some questions did not receive sufficient feedback for analysis. The authors have only provided discussions on questions in which at least $60 \%$ of all respondents answered.

Engineering self-efficacy

There are two subscales for engineering self-efficacy on the LAESE survey. The Engineering self-efficacy I subscale has five items and the Engineering self-efficacy II subscale has six items. We received sufficient student responses to two engineering self-efficacy items. The results for each of these two self-efficacy items are shown below in Table 6 .

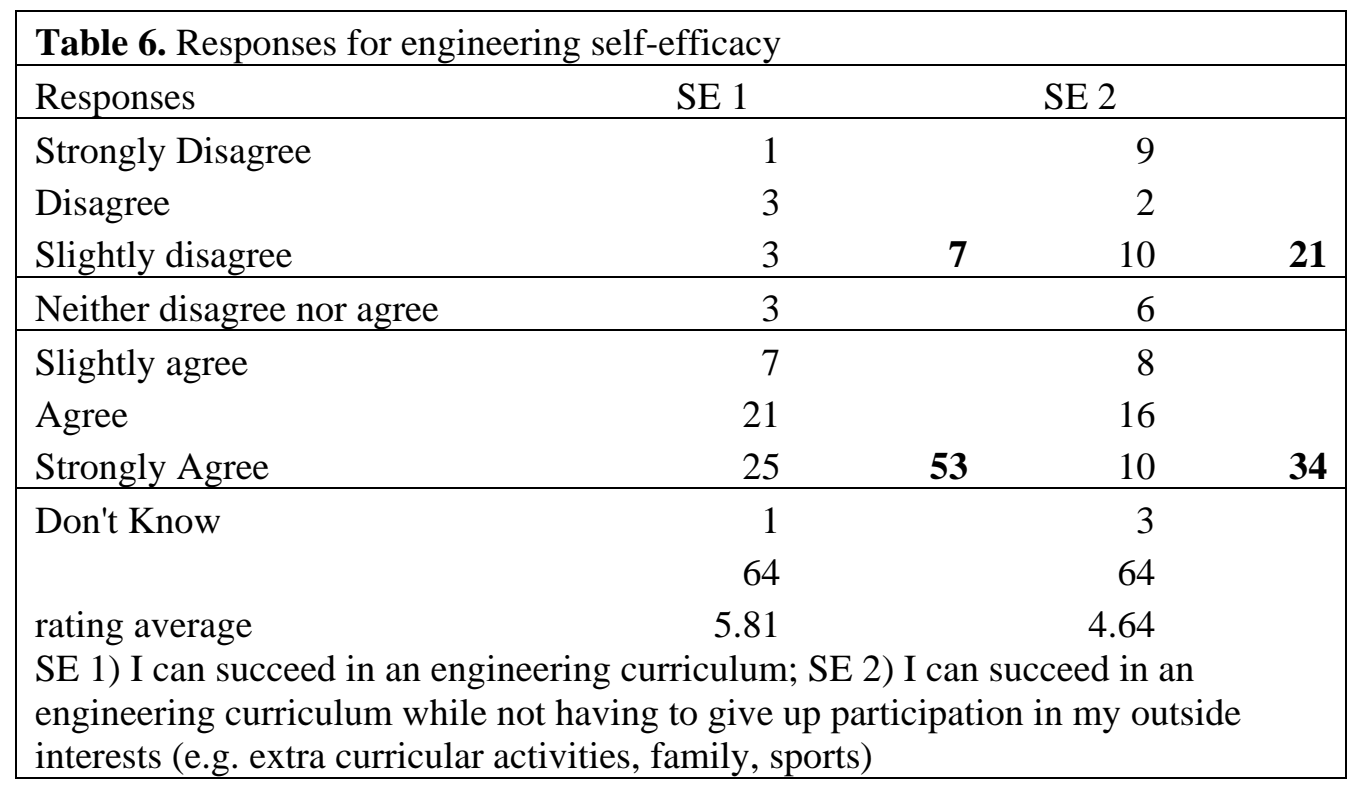

An overwhelming majority of women engineering students are confident in their ability to succeed in an engineering curriculum; 53 out of 64 women engineering students were in agreement with this statement. Fewer women engineering students were confident that they could succeed in engineering while not having to give up participation in outside interests (only 34 out of 64 students). These conflicting results can possibly be explained by the characteristics of students at San José State University . San José State University has a high proportion of first generation college students who have commitments to their families and communities.

Engineering career success expectations

One item for the engineering career success expectations subscale had sufficient student responses to analyze. The rating average for this item was 6.05; this indicates that the respondents agreed or strongly agreed that "someone like me can succeed in an engineering career.” Indeed, 47 out of the 64 respondents to this item indicated that they agreed or strongly agreed with the statement.

Feelings of inclusion 
The Feeling of Inclusion subscale has four items. All of these items had sufficient student response to analyze. Table 7 displays the student responses for the four items in this subscale. For each of the four items, the rating averages were lower than the other items analyzed (except for SE 2). This relates to an average rating of "Slightly agree" for these items.

Table 7. Student responses for the "Feeling of Inclusion" subscale

\begin{tabular}{|c|c|c|c|c|c|c|c|c|}
\hline Item & $\mathrm{FI} 1$ & & FI 2 & & $\mathrm{FI3}$ & & FI4 & \\
\hline Strongly Disagree & 2 & & 2 & & 2 & & 3 & \\
\hline Disagree & 6 & & 5 & & 5 & & 3 & \\
\hline Slightly disagree & 4 & 12 & 5 & 12 & 4 & 11 & 0 & 6 \\
\hline Neither disagree nor agree & 4 & & 6 & & 4 & & 7 & \\
\hline Slightly agree & 14 & & 13 & & 18 & & 9 & \\
\hline Agree & 23 & & 22 & & 17 & & 23 & \\
\hline Strongly Agree & 9 & 46 & 7 & 42 & 7 & 42 & 16 & 48 \\
\hline \multirow[t]{2}{*}{ Don't Know } & 1 & & 3 & & 6 & & 1 & \\
\hline & 63 & & 63 & & 63 & & 62 & \\
\hline rating average & 5.1 & & 5.1 & & 5.22 & & 5.48 & \\
\hline
\end{tabular}

FI 1) I can relate to the people around me in my class; FI 2) I have a lot in common with the other students in my classes; FI 3) The other students in my classes share my personal interests; FI 4) I can relate to the people around me in my extra-curricular activities

\section{Discussion}

Despite its location in a region with a high demand for engineering graduates, the College of Engineering at San José State University has seen a gradual decline in the numbers of women undergraduate engineering students from 751 in Fall 2001 to 440 in Fall 2011; this represents a percentage decrease from $18.8 \%$ to $13.9 \%$ during this time period. The percent of women undergraduate engineering students at San José State University is lower than nationwide averages.

This research was undertaken to determine the motivations of women students at San José State University to pursue engineering careers, including their level of self-efficacy. Despite the shrinking number of women engineering students at San José State University , the self-efficacy levels of the women engineering students were high. The authors can surmise that women who choose to study engineering at SJSU feel confident in their abilities to succeed in engineering and or project such confidence given the male-dominated terrain of Engineering. It would be interesting to trace out the self-efficacy levels of women engineering students at different class levels ( $1^{\text {st }}$ year vs final year in college). To what extent might self-efficacy increase and or decrease as a female engineering student advances through the Engineering academic pathway?

The researchers will conduct focus groups with junior and senior-level students pursuing engineering majors (50 males and 50 females) in Spring 2012 to elicit more information about the students' experiences at SJSU. The authors will ask questions related to what helped them succeed in engineering; what advice do they have for incoming students; and the cultural and familial influences on their career choices. 


\section{Bibliography}

1 Sadker, M., \& Sadker, D. M. (1994). Failing at fairness: How America's schools cheat girls. New York: Scribner.

2 Gushue, G.V., \& Whitson, M.L. (2006). The relationship of ethnic identity and gender role attitudes to the development of career choice goals among Black and Latina girls. J Counsel Psychology 53 (3), 379-385.

3 King, K. (2004). Women and girls in mathematics: A view through the pipeline. Presentation from The Progress and Challenges of Women and Girls in Education and Work. Princeton, NJ: ETS. Obtained December 28, 2006 from http://www.ets.org/Media/Research/pdf/conf_achgapwomen_king.pdf.

4 Valenzuela, A. (1999). Subtractive schooling. State University of New York Press.

5 Trenor, J. M., \& Yu, S. L. (2008, December). Diversity within diversity. ASEE Prism, p. 51.

6 Niemann, Y.F. (2001). Stereotypes about Chicanas and Chicanos. Coun Psych 29, 55-90.

7 Gloria, A. M. \& Robinson Kurpius, S. E. (1996). The validation of the Cultural Congruity Scale and the University Environment Scale with Chicano(a) students. Hispanic Journal of Behavioral Sciences 18, 533-549.

8 Schunk, D. H., \& Pajares, F. (2002). The development of academic self-efficacy. In Development of achievement motivation (pp. 15-31). San Diego: Academic Press.

9 Rittmayer, M.A. \& Beier, M.E. (2009). Self-Efficacy in STEM. In B. Bogue \& E. Cady (Eds.). Applying Research to Practice (ARP) Resources.

10 American Association of University Women. (2008). Women and girls in STEM. Washington, DC: Author.

11 Engineering Workforce Commission (2009). Engineering and Technology Degrees, 2009. Washington, DC: author.

12 Rittmayer, A. D. \& Beier, M. E. (2009). Self-Efficacy in STEM. In B. Bogue \& E. Cady (Eds.). Applying Research to Practice (ARP) Resources. Retrieved December 12, 2011 from http://www.engr.psu.edu/AWE/ARPresources.aspx

13 Bandura, A. (1997). Social cognitive theory of self-regulation. Org Beh \& Hum Dec Procs, 50, 248-287.

14 Pajares, F. (2005). Gender difference in mathematics self-efficacy beliefs. In A. M. Gallagher \& J. C. Kaufman (Eds.), Gender differences in mathematics: An integrative psychological approach (pp. 294-315). New York: Cambridge University Press.

15 Bandura, A., \& Locke, E. A. (2003). Negative self-efficacy and goals effects revisited. Journal of Applied Psychology, 88, 87-99.

16 Britner, S. L., \& Pajares, F. (2006). Sources of science self-efficacy beliefs of middle school students. Journal of Research in Science Teaching, 43, 485-499.

17 Watt, H. M. G. (2006). The role of motivation in gendered educational and occupational trajectories related to maths. Educational Research and Evaluation, 12, 305-322.

18 Lent, R. W., Brown, S. D., Schmidt, J., Brenner, B., Lyons, H. \& Treistman, D. (2003). Relation of contextual supports and barriers to choice behavior in engineering majors: Test of alternative social cognitive models. Journal of Counseling Psychology, 50(4), 458-465.

19 Matsui, T., Matsui, K., \& Ohnishi, R. (1999). Mechanisms underlying math self-efficacy learning of college students. Journal of Vocational Behavior, 37(2), 225-238.

20 Mau, W. C. (2003). Factors that influence persistence in science and engineering career aspirations. Career Development Quarterly, 51, 234-243.

21 Brainard, S. G., \& Carlin, L. (1998). A six-year longitudinal study of undergraduate women in engineering and science. Journal of Engineering Education, 87(4), 369-375.

22 Hutchinson-Green, M. A., Follman, D. K., \& Bodner, G. M. (2008). Providing a voice: Qualitative investigation of the impact of a first-year engineering experience on students' self-efficacy beliefs. Journal of Engineering Education, 97(2), 177-190.

23 Jackson, L. A., Gardner, P. D., \& Sullivan, L. A. (1993). Engineering persistence: Past, present, and future factors and gender differences. Higher Education, 26, 227-246.

24 Pajares, F. (1996). Self-efficacy beliefs in academic settings. Review of Educational Research, 66(4), 543-578.

25 Hutchinson-Green, M. A., Follman, D. K., \& Bodner, G. M. (2008). Providing a voice: Qualitative investigation of the impact of a first-year engineering experience on students' self-efficacy beliefs. Journal of Engineering Education, 97(2), 177-190.

26 Pajares, F., \& Miller, M. D. (1994). The role of self-efficafy and self-concept beliefs in mathematical problemsolving: a path analysis. Journal of Educaitonal Psychology, 86(2), 192-203. 
27 Besterfield-Sacre, M., Moreno, M., Shuman, L. J., \& Atman, C. J. (2001, October). Gender and ethnicity differences in freshmen engineering student attitudes: A cross-institutional study, Journal of Engineering Education, 90, 477-489.

28 Concannon, J. O., \& Barrow, L. H. (2009). A cross-sectional study of engineering students' self-efficacy by gender, ethnicity, year, and transfer status. Journal of Science Education and Technology, 18(2), 163-172.

29 Meinholdt, C., \& Murray, S. L. (1999). Why aren’t there more women engineering? Journal of Women and Minorities in Science and Engineering, 5, 239-263.

30 Brainard, S. G., \& Carlin, L. (1998). A six-year longitudinal study of undergraduate women in engineering and science. Journal of Engineering Education, 87(4), 369-375.

31 Marra, R. M \& Bogue, B. (2006). Women engineering students's self-efficacy—a longitudinal multiinstitutional study. Proceedings of the 2006 WEPAN Conference. Available: http://www.engr.psu.edu/awe/misc/ResearchPagePDFs/120_Marra-Women.pdf

32 Reisberg, R., Bailey, M., Burger, C., Hamann, J., \& Raelin, J., \& Whitman, D. (2010). The effect of gender on support and self-efficacy in undergraduate engineering programs. Proceedings of the 2010 ASEE Annual Conference. Available: http://www.coe.neu.edu/pathways/EffectofGender.pdf

33 Concannon, J. O., \& Barrow, L. H. (2009). A cross-sectional study of engineering students' self-efficacy by gender, ethnicity, year, and transfer status. Journal of Science Education and Technology, 18(2), 163-172.

34 AAUW (2004).Under the microscope. A decade of gender equity projects in the sciences. Washington, DC: Author. Obtained December 28, 2006 from http://www.aauw.org/research/underthemicroscope.pdf.

35 Shettle, C., Roey, S., Mordica, J., Perkins, R., Nord, C., Teodorovic, J., Brown, J., Lyons, M., Averett, C., \&Kastberg, D. (2007).The nation's report card: America's high school graduates (NCES 2007-467).

Washington, DC: National Center for Education Statistics, Institute of Education Sciences, U.S. Department of Education.

36 Berryman, S. E. (1983). Who will do science? New York: The Rockefeller Foundation.

37 Xie, Y., \& Shauman, K. (2003). Women in science. Boston: Harvard University Press.

38 Malicky, D. (2003). A literature review on the under-representation of women in undergraduate engineering: Ability, self-efficacy, and the "chilly climate." Proceedings of the 2003 ASEE Annual Conference. Available: http://uconngalileo.engr.uconn.edu/upload/papers/1932.pdf

39 Kulis, S., Sicotte, D., \& Collins, S. (2002). More than a pipeline problem: Labor supply constraints and gender stratification across academic science disciplines. Research in Higher Education, 43(6), 657-691.

40 Kertzer, D. (1991). Household and gender in a life-course perspective. In E. Masini \& S. Stratigos (Eds.), Women, households and change. Shibuya-ku, Tokyo 150, Japan: United Nations University Press.

41 http://www.engr.psu.edu/awe/secured/director/diversity/efficacy.aspx

42 Marra, R. M. \& Bogue, B. (2006). Women engineering students' self- efficacy: A longitudinal multi-institution study. Proceedings of the 2006 WEPAN Conference. Available: http://www.engr.psu.edu/awe/misc/ResearchPagePDFs/120_Marra-Women.pdf. 